\title{
MEDIDA DE SEGURANÇA NO DIREITO PENAL BRASILEIRO: ESTUDO SOBRE VIOLÊNCIA E (IN)EFICÁCIA DOS HOSPITAIS DE CUSTÓDIA
}

\author{
SECURITY MEASURE IN BRAZILIAN CRIMINAL LAW: STUDY ABOUT VIOLENCE AND (IN) \\ EFFICIENCY OF CUSTODY PSYCHIATRIC HOSPITALS
}

\author{
Samuel Mendonça ${ }^{1}$ \\ Christiany Pegorari Conte ${ }^{2}$ \\ Beatriz Ferruzzi Sacchetin ${ }^{3}$
}

\begin{abstract}
Resumo: A medida de segurança é o instituto do Direito Penal responsável pelo tratamento dos inimputáveis e pode se dar nas modalidades de internação e tratamento ambulatorial. A modalidade de internação vai na contramão de todos os princípios e ideias colocados durante a reforma psiquiátrica, bem como é contrária à própria Lei da Reforma Psiquiátrica, que busca a desinstitucionalização de indivíduos com transtornos mentais. A pesquisa, assim, buscou realizar uma avaliação desse instituto na modalidade de internação a fim de saber se é eficaz à proposta de tratamento dos pacientes no que tange o seu discurso oficial de tratamento. Foi realizada análise bibliográfica dentro do âmbito do Direito Penal e da Criminologia, além de estudo analítico de materiais empíricos produzidos sobre Hospitais de Custódia e Tratamento Psiquiátrico, buscando assimilar melhor a dinâmica desse instituto. Foi possível compreender, a partir da perspectiva da Criminologia Crítica, que há uma ineficácia na modalidade de internação ao que se propõe, todavia, essa ineficácia se enquadra apenas no discurso oficial de tratamento dos sujeitos. O discurso real da medida de segurança propõe a sua segregação por não serem capazes de se enquadrar na lógica produtiva do capital, e para isso a internação se mostrou absolutamente eficaz, já que afasta os sujeitos de seu convívio familiar de seus afetos externos à custódia.
\end{abstract}

Palavras-chave: Medida de segurança. Inimputabilidade. Saúde Mental. Reforma psiquiátrica.

\begin{abstract}
The security measure is the institution of Criminal Law responsible for the treatment of the unimputable individuals and it can be done through hospitalization or clinical care. The hospitalization goes against all the principles and ideas that came along with the Psychiatric Reform Movement, and against the Law of Psychiatric Reform itself, which seeks the deinstitutionalization of the individuals with mental illness. In this research it was intended to do an evaluation of the security measure through hospitalization, so it would be possible to know if the plan to treat these patients was effective regarding the official discourse as a treatment. A bibliographic analysis was made in the scope of Criminal Law, Criminology in addition to analytical study about empirical material produced about Custody and Psychiatric Treatment Hospitals, seeking to absorb the dynamics of the institution. It was possible to comprehend, from the perspective of the Critical Criminology, that the hospitalization is inefficient to its purpose, however, this inefficiency is only in the official discourse in the treatment of these subjects. The real discourse of the security measure establishes the segregation of these people once they are not capable of fitting in the logic of production of
\end{abstract}

\footnotetext{
Doutor em Filosofia da Educação pela Universidade Estadual de Campinas; Mestre (área de Ética), Licenciado e Bacharel em Filosofia pela Pontifícia Universidade Católica de Campinas; Professor Titular, vinculado ao Programa de Pósgraduação em Direito, Mestrado Acadêmico, linha de pesquisa Direitos Humanos e Políticas Públicas, grupo de pesquisa Direito e Realidade Social, e ao Programa de Pós-Graduação em Educação, Mestrado e Doutorado, linha de pesquisa Políticas Públicas em Educação, da Pontifícia Universidade Católica de Campinas; https://orcid.org/0000-0002-29180952; samuelms@gmail.com

2 Mestre em Direito da Sociedade da Informação pelo Centro Universitário das Faculdades Metropolitanas Unidas; doutoranda em Educação pela Pontifícia Universidade Católica de Campinas; Professora de Direito Penal e Processual Penal da graduação, pós-graduação e extensão da Pontifícia Universidade Católica de Campinas; https://orcid.org/0000-00026152-4735; chrispegorari08@gmail.com

3 Especialista na área de Educação pela Universidade do Oeste Paulista; mestranda em Direito Político e Econômico pela Universidade Presbiteriana Mackenzie; https://orcid.org/0000-0003-1088-5765; biafesa@hotmail.com
} 
the capital, and for that the hospitalization has shown itself very effective, once it sets apart the subjects from their family and from their loved ones outside the custody.

Keywords: Security measure. Legal irresponsibility. Mental Health. Psychiatric Reform Movement.

Recebido em 1 de abril de 2019 Avaliado em 12 de novembro de 2020 (AVALIADOR A) Avaliado em 17 de novembro de 2020 (AVALIADOR B) Avaliado em 8 de novembro de 2020 (AVALIADOR C) Aceito em 17 de novembro de 2020

\section{Introdução}

O Brasil convive com uma situação calamitosa de encarceramento em massa e apresenta uma realidade extremamente degradante e desumana aos indivíduos encarcerados (SILVESTRE; LINS DE MELO, 2017). A literatura a respeito desse tema é vasta e abrange estudos teóricos a respeito dos direitos humanos, pesquisas empíricas, trabalhos de campo que comprovam as violações a que são submetidos os presos no país e diversos relatórios que atestam a situação precária do cárcere brasileiro. ${ }^{4}$ No contexto da política editorial da Espaço Jurídico Journal of Law que publica artigos que tratam da efetividade dos direitos constitucionais fundamentais, com ênfase nos direitos sociais e civis, que se entendeu pertinente oportunizar para os leitores do prestigiado periódico o resultado da investigação feita em um Programa de Pós-Graduação do Sistema Nacional de Pós-Graduação.

Nesse contexto, o Direito é um instrumento utilizado por aqueles que se encontram nas camadas mais altas da sociedade para ali permanecerem: é um dos meios fundamentais pelo qual o status quo político, econômico e social é capaz de se manter, e para essa manutenção é fundamental que as lógicas opressoras sejam perpetuadas (SANTOS, 1981). No âmbito do Direito Penal, esse mecanismo se torna ainda mais evidente, uma vez que tal vertente punitiva do Estado possui, na prática, o papel de segregação, encarceramento e exclusão das pessoas de classes mais baixas, de raças historicamente oprimidas e de indivíduos com características não aceitas pelo padrão social imposto. Deste modo, a preocupação em veicular os casos de violações na mídia ou promover discussões é muito reduzida, por não ser um tema que afeta direta e negativamente aqueles em posições de poder.

Assim, considerando a cifra oculta da criminalidade, é possível diagnosticar a grande seletividade do sistema criminal e os processos de criminalização seletiva de grupos minoritários. A violência se constrói enquanto um processo parcial e, assim, mesmo a criminalidade sendo cometida pela maior parte dos cidadãos, o processo de criminalização ocorre apenas para uma parcela muito limitada de pessoas (ANDRADE, 1994). Aqueles que se enquadram em um "tipo-ideal" do criminoso são os mesmos que serão encarcerados e terão seus direitos violados por meio desse processo de criminalização, conforme o que se pode confirmar a partir dos próprios dados do Infopen

\footnotetext{
4 Relatórios do Infopen (2016) e do Conselho Nacional de Justiça (2018).
} 
(DEPARTAMENTO PENITENCIÁRIO NACIONAL; MINISTÉRIO DA JUSTIÇA E SEGURANÇA PÚBLICA, 2016).

Dentro do estudo do Direito Penal, e mais especificamente na análise a respeito do encarceramento no país, as áreas que envolvem os direitos das minorias se mostram de extrema relevância a serem destacadas pela Academia, uma vez que revelam diversas formas de violações aos direitos fundamentais. Nesse sentido, as pessoas com transtornos mentais são incluídas nessa lógica segregacionista e possuem um lugar de fala ainda mais precário para denunciar as violações a que são submetidas, sendo mais silenciadas. A parcela da população prisional representada pelas pessoas em cumprimento de medida de segurança é bastante pequena, mas "[...] essa insignificância estatística possui o efeito perverso de induzir a falsa suposição de que o problema não existe, ou quiçá de que não é tão grave, notadamente porque o silêncio dos manicômios judiciários não produz rebeliões ou manchetes." (AZEVEDO; CAPRA, 2018, p. 127).

A literatura aponta que, após serem internadas, essas pessoas perdem qualquer contato com o mundo externo ao hospital e passam a viver apenas a realidade da internação, que é degradante e violadora de seus direitos humanos (LANCETTI, 2001; SEVERO, 2009). Ademais, o tratamento dedicado aos pacientes nem sempre é o adequado e o tempo que ficam internados é superior ao previsto, pela demora na realização dos exames de cessação de periculosidade, por exemplo. Especialistas em saúde mental afirmam que a melhor maneira para que haja um tratamento efetivo dessas pessoas é o tratamento diverso da internação, de modo a evitar o afastamento do indivíduo de seus familiares e conhecidos, todavia, a prática do Direito Penal insiste em interná-los como medida de redução da periculosidade (PRADO; SCHINDLER, 2017). Assim sendo, a violação aos direitos desses pacientes gera uma ineficácia na proposta da medida de segurança, que seria o tratamento, a suposta cessação de periculosidade e ressocialização desses indivíduos.

Ainda, esses sujeitos considerados inimputáveis possuem representação limitadíssima em meio à mídia e ao meio jurídico, invisibilizados inclusive pelos periódicos de ciências criminais no país (BRANCO; ÁVILA; CARVALHO, 2019), e isso faz com que a importância do assunto muitas vezes seja minimizada. Portanto, é papel da Academia e de outras instituições de fiscalização o relato e denúncia a respeito das situações de violações a fim de que possam ser elaboradas políticas públicas que visem à efetivação dos direitos fundamentais e do tratamento de qualidade desses sujeitos.

A pergunta que se fez, portanto, a partir da análise de variáveis como o contato do paciente com familiares ou afetos externos ao hospital, tempo para realização do exame criminológico e tempo de permanência no hospital para o tratamento, foi se a medida de segurança em internação se mostra eficaz em relação ao seu objetivo oficial de tratamento ou se é configurada a partir de suas funções não-declaradas de exclusão e segregação de uma minoria social. A hipótese principal do trabalho era a de que na realidade a medida de segurança em internação é absolutamente despreocupada com os direitos fundamentais dos sujeitos que a ela se encontram submetidos, violando princípios 
constitucionais e as diretrizes da Reforma Psiquiátrica, confirmando o seu real papel de política de controle e morte das pessoas com transtorno mental.

Para que os objetivos pudessem ser alcançados, foi realizado estudo analítico de trabalhos empíricos com informações referentes aos pacientes internados em hospitais de custódia, com base em três trabalhos com grande robustez de dados: o levantamento sobre o Censo de 2011 dos estabelecimentos de custódia e tratamento psiquiátrico, publicado por Débora Diniz, em 2013; a pesquisa realizada no Hospital de Custódia e Tratamento Psiquiátrico da Bahia, por Prado e Schindler, publicada em 2017; e o levantamento de dados no Instituto Psiquiátrico Forense de Porto Alegre/RS, por Azevedo e Capra, publicado em junho de 2018.

A fim de que se pudesse realizar essa análise de dados com clareza, foi realizada uma breve apreciação crítica dos aspectos dogmáticos do instituto da culpabilidade e da excludente da inimputabilidade, bem como dos fundamentos da medida de segurança dentro do sistema penal, a partir da perspectiva da criminologia crítica, com raiz na teoria marxista, que embasou a crítica realizada aos fundamentos do instituto da medida de segurança na modalidade de internação e a análise dos dados selecionados.

\section{Matriz teórica: criminologia crítica}

Ao longo do desenvolvimento histórico da Criminologia, diversas escolas se desenvolveram a partir da visão do consenso, partindo do pressuposto que há uma estabilidade social e que o crime é algo alheio a esse arranjo. Trouxeram importantíssimas considerações a respeito dos objetos de estudo da Criminologia, ,todavia, não foram capazes de compreender a sociedade a partir dos embates entre diferentes grupos sociais, papel exercido pela visão das teorias do conflito, surgidas em meados do século XX. As teorias do conflito abrangem, mais tradicionalmente, a teoria do etiquetamento (ou labelling approach) e a criminologia crítica (ou criminologia radical, de acordo com o termo preferido pelo professor Juarez Cirino dos Santos), ${ }^{5}$ além de visões contemporâneas como a criminologia feminista, criminologia negra, criminologia cultural ou criminologia queer. Assim, partem dos pressupostos de que:

[...] toda a sociedade está, a cada momento, sujeita a processos de mudança; a mudança social é ubíqua; toda sociedade exibe a cada momento dissensão e conflito e o conflito social é ubíquo; todo elemento em uma sociedade contribui de certa forma para sua desintegração e mudança; toda sociedade é baseada na coerção de alguns de seus membros por outros. (DAHRENDORF apud SHECAIRA, 2018, p. 180).

\footnotetext{
5 Importante ressalvar que a divisão entre escolas e teorias sempre se faz por fins didáticos e de melhor entendimento, mas estas não se desenvolvem de maneira linear e nem se subdividem com tão grande clareza como possa parecer: influências recíprocas são exercidas e há manutenção dos pensamentos ao longo dos anos, sem rupturas responsáveis por extinguir e criar novas escolas ou teorias.
} 
Essas teorias se interessam mais pela ideia do controle social e da estrutura social do que propriamente pelas causalidades do crime e do estudo do criminoso, e dentro delas, as reflexões produzidas pela teoria do etiquetamento são de enorme relevância para essa temática, uma vez que buscam compreender exatamente o controle social exercido pelas instituições totais e neste trabalho a análise é centrada justamente em unidades de internação de pacientes-presidiários (GOFFMAN, 2010). Entretanto, a criminologia crítica, também estabelecida na perspectiva das teorias do conflito traz, ainda, uma análise macrossociológica de base marxista, que enxerga o sistema punitivo através de sua inserção no sistema capitalista e atrela o sistema de punição ao sistema de produção.

Diversos autores apresentaram suas reflexões a partir dessa matriz de pensamento, como Rusche e Kirchheimer (2004), Melossi e Pavarini (2006), Baratta (2000), internacionalmente, e Santos (1981), no Brasil. Importantes contribuições foram também as de Michel Foucault (especialmente em sua obra Vigiar e Punir (2003)), que não desenvolveu todo o seu trabalho exclusivamente sobre o sistema penal, mas suas considerações foram de grande relevância para o desenvolvimento da criminologia crítica.

Essa perspectiva da criminologia se utiliza do método dialético em suas análises, já que possui base marxista, e propõe o debate entre seus objetos, que são "as relações sociais de produção (estrutura de classes) e de reprodução político-jurídica (superestrutura de controle)." (SANTOS, 1981, p. 86). Propõe que haja um afastamento tanto do determinismo biológico quanto da ideia do livre arbítrio da escola clássica e dos condicionamentos sociais do positivismo sociológico para uma análise com base na estrutura econômica e na superestrutura política e jurídica. Deste modo, apresenta a proposição de revolução de todo o sistema penal e prisional juntamente com a revolução do sistema político-econômico, a fim de fazer com que esse sistema deixe de existir puramente para o serviço aos interesses do capital.

Para que a pena possa ser estabelecida dentro do sistema penal, as mais diversas justificativas surgiram ao longo da história: da pena como retribuição, trazida por autores da filosofia idealista ocidental, como Kant; pena como prevenção especial, como uma espécie de "ortopedia moral", no termo utilizado por Foucault; e da pena como prevenção geral - negativa, como propõe a teoria da coação psicológica de Feuerbach, ou positiva, relacionada à proteção de bens jurídicos, como propunha Luhmann (SANTOS, 2017, p. 427). Ocorre que a visão crítica a respeito da função da pena não aceita esse discurso oficial produzido e coloca que existem objetivos reais e ideológicos da pena.

Pasukanis (1988) traz uma importantíssima reflexão nesse sentido, sobre a natureza ideológica do direito, sendo assim possível a divisão entre objetivos reais e ideológicos da pena. Os objetivos reais são a proteção dos privilégios fundados na propriedade privada dos meios de produção, a luta contra as classes oprimidas ou a garantia da dominação de classes e da desigualdade social. Enquanto os objetivos ideológicos da pena envolvem a proteção da sociedade, mas se trata apenas de um discurso que não correspondem à realidade. Inclusive é por isso, de acordo com o autor, 
que o critério de medição e valoração da pena na sociedade capitalista é justamente o tempo: pois é a base do sistema de produção de mais-valia através da exploração do proletariado.

Ainda na mesma perspectiva de discurso, Rusche e Kirchheimer (2004) formulam a tese que os sistemas político-econômicos configurados ao longo da História tendem a encontrar o mecanismo punitivo mais eficiente para colaborar com a manutenção de si mesmos:

O sistema penal de uma sociedade não é um fenômeno isolado sujeito apenas às suas leis especiais. É parte de todo o sistema social, e compartilha suas aspirações e seus defeitos. A taxa de criminalidade pode de fato ser influenciada somente se a sociedade está numa posição de oferecer a seus membros um certo grau de segurança e de garantir um nível de vida razoável. (RUSCHE; KIRCHHEIMER, 2004, p. 282).

Foucault (2003), em seu renomado livro "Vigiar e punir", apresenta a ideia similar, de que apesar de o sistema prisional parecer óbvio na lógica contemporânea de funcionamento da sociedade, ele nada mais é que uma adaptação a esse funcionamento:

Pode-se compreender o caráter de obviedade que a prisão-castigo muito cedo assumiu. Desde os primeiros anos do século XIX, ter-se-á ainda consciência de sua novidade; e entretanto ela surgiu tão ligada, e em profundidade, com o próprio funcionamento da sociedade, que relegou ao esquecimento todas as outras punições que os reformadores do século XVIII haviam imaginado. (FOUCAULT, 2003, p. 195).

A bibliografia a respeito da criminologia tem foco especial no sistema prisional comum, todavia, não raramente são feitas ressalvas de que a lógica também é aplicada à medida de segurança. Inclusive, uma parte considerável da literatura se preocupa em grande medida com os hospitais psiquiátricos e as internações, como é o caso de Goffman (2010), anteriormente citado. Deste modo, apesar de não haver a aplicação de pena aos inimputáveis, a medida de segurança segue a mesma lógica segregacionista e de busca pela manutenção do sistema através do sistema penal.

De acordo com Miranda (2004), a deficiência sempre foi questão absolutamente complexa na humanidade e as pessoas que apresentassem qualquer tipo de transtorno ou deficiência sofriam com a qualificação de "sub-humanos". Três paradigmas se apresentaram ao longo da história: o paradigma do abandono, em que os indivíduos com necessidades especiais, de maneira geral, eram excluídos, tendo que ficar em áreas exteriores às aglomerações urbanas; o paradigma dos serviços, pois com as guerras, os deficientes passaram a ser utilizados como mão-de-obra barata; e o paradigma da institucionalização, em que não eram mais "excluídos", mas eram apenas integrados em centros especializados - e não incluídos de maneira efetiva na vida social. Pode-se perceber com clareza, também, a lógica do sistema econômico de cada época atuando sobre a segregação ou integração dessas pessoas à sociedade e à lógica produtiva. 
Por esse motivo, do mesmo modo em que a perspectiva crítica da criminologia não permite que a justificativa para as penas seja compreendida de acordo com o discurso oficial (tanto na ideia da pena como retribuição quanto como prevenção geral ou especial), não permite que essa justificativa seja aplicada à medida de segurança. Assim, para que se compreenda o instituto de maneira adequada, não se pode levar em conta apenas o papel ideológico da internação de pacientes após sua absolvição imprópria, mas também o papel real desse instituto.

Desse modo, quando se fala em "ineficácia" da medida de segurança na temática da presente pesquisa, há a implicação de uma falência do Estado na aplicação do instituto em relação ao seu discurso oficial. Significa dizer que o Estado se presta à ressocialização e tratamento dos pacientes-presidiários para sua reinserção na sociedade, mas falha nessa prestação. Todavia, essa ressocialização é apenas o discurso oficial trazido pelo Direito Penal para justificar a medida de segurança, da mesma maneira que ocorre com a pena.

Nesse sentido, em relação ao discurso crítico, a medida de segurança assim como a pena comum, é absolutamente eficaz ao que se propõe a fazer, que é justamente a garantia dos privilégios com base na propriedade privada e a garantia da opressão de determinadas classes sobre outras. Por isso, importante a consciência de que a utilização do termo "ineficácia" está inserida na lógica do discurso oficial e deve sempre ser problematizada.

A segregação das pessoas com deficiência, assim, se deu de diferentes maneiras ao longo dos séculos, acompanhando a lógica percebida em relação às penas regulares: de acordo com a necessidade dos sistemas econômicos, surge um novo meio de punição para que o sistema seja capaz de se manter. Ocorre que devido à deficiência desses sujeitos, o seu grau de "utilidade" ao sistema econômico capitalista é reduzido em relação a outro sujeito qualquer - e, portanto, há um desinteresse muito maior na humanização desse tratamento e da integração desses sujeitos ao sistema. Então, a efetividade do sistema de punição em relação a esses sujeitos para a manutenção do status quo do sistema econômico é ainda mais brutal e envolve uma dose muito mais cruel de exclusão e segregação.

\section{0 instituto da culpabilidade}

Em uma crítica à configuração dogmática da medida de segurança, assim, importante compreender a noção de inimputabilidade como excludente da culpabilidade. O crime é conceituado como todo fato típico, ilícito e culpável pela parte majoritária da doutrina brasileira (embora alguns autores como Santos (2017) prefiram a noção bipartida de crime), e a conduta que se enquadra nesse conceito, por ter sido determinada como crime, deve ser punida com a sanção adequada, nos termos da lei e dos princípios gerais pertinentes à matéria. Não há necessidade de atenção especial aqui aos dois primeiros elementos do crime, uma vez que o recorte da presente pesquisa é precisamente a investigação a respeito da eficácia da aplicação da medida de segurança nos casos de inimputabilidade 
penal, causa excludente da culpabilidade. Nesse caso, faz-se necessário exame a respeito do conceito de culpabilidade e a respeito de sua excludente pela inimputabilidade.

A culpabilidade é um princípio constitucional, que garante a pessoalidade e a proporcionalidade na aplicação de pena aos cidadãos, limitando, assim, o poder punitivo estatal e estabelecendo diretrizes para que os direitos fundamentais dos sujeitos não sejam violados (CAETANO, 2019). Fundamenta-se nas ideias de que "nenhuma pena passará da pessoa do condenado" e "ninguém será considerado culpado até o trânsito em julgado de sentença penal condenatória", conforme estabelecido no artigo $5^{\circ}$, incisos XLV e LVII da Constituição Federal (BRASIL, 1988). Portanto, a aplicação do princípio da culpabilidade no momento da identificação de autoria e materialidade de uma conduta criminosa é essencial para que se garanta os direitos fundamentais dos cidadãos brasileiros.

Ocorre que quando há constatação de que o sujeito acusado apresenta uma situação de inimputabilidade, não há avaliação de sua culpabilidade, a partir de uma evidente infração ao princípio constitucional e cerceando de maneira clara seu direito à defesa. Santos (2017) define a imputabilidade como a aptidão para ser culpável, ou seja, a capacidade de compreender a ilicitude da conduta a ser tomada, bem como a capacidade de agir conforme esse entendimento. A lógica aplicada às situações de inimputabilidade, portanto, é de que os sujeitos não são capazes de compreender que a conduta que estão praticando é ilícita, ou então, apesar de terem essa compreensão, não são capazes de agir de maneira diversa.

A avaliação da inimputabilidade é realizada a partir do laudo pericial no incidente de insanidade mental, utilizando-se das áreas psi apenas para a produção desses documentos, sem a preocupação de consultá-las para saber de suas próprias demandas e das demandas em relação à saúde dos sujeitos acusados em questão. Ademais, desenvolve-se uma problemática muito séria em relação às provas, que passam a fazer parte de um sistema tarifado, já que os laudos médicos acabam por se configurar enquanto provas absolutas e inquestionáveis ao longo do processo penal (WEIGERT, 2017; CARVALHO, 2020). É possível perceber com clareza a partir desse mecanismo que o discurso de poder médico-psiquiátrico é utilizado como um saber legitimante do poder punitivo estatal e de suas estruturas opressivas (BRANCO, 2019).

A partir da constatação de que a pessoa é inimputável (ou seja, possui um diagnóstico de psicopatologia, não teve compreensão sobre o caráter ilícito do fato ou não pôde se determinar de acordo com esse entendimento), o fundamento para a aplicação do tratamento da medida de segurança passa a ser a periculosidade desse sujeito, e não sua culpabilidade. Esse fundamento está relacionado à previsão de potenciais comportamentos criminosos que a pessoa possa vir a cometer e aplica um tratamento com finalidade exclusivamente preventivo-especial (SÁ; ALVES; ZIMMARO, 2013).

A aplicação da medida de segurança com base na inimputabilidade, ou inaptidão para a culpabilidade, dá-se, assim, exclusivamente às pessoas diagnosticadas com psicopatologia, em um 
tratamento absolutamente discriminatório em relação ao restante da população. Infringe diretamente as disposições constitucionais e de convenções e estatutos que protegem a pessoa com deficiência. Atribui-se uma característica de periculosidade inerente ao sujeito meramente pela existência de um diagnóstico de psicopatologia que lhe foi atribuído (LEBRE, 2013).

Em outros momentos históricos, a culpabilidade esteve diretamente atrelada à noção de responsabilidade e possibilidade de livre-arbítrio, fazendo com que pessoas classificadas como "inferiores" não fossem passíveis de responsabilização por seus crimes, já que eram "naturalmente" criminosas e não tinham possibilidade de escolha sobre realizar ou não a conduta. Esse foi o caso das mulheres durante a Idade Média (ZAFFARONI, 2012) e também foi a mesma lógica utilizada em relação à loucura a partir do século XVIII. Assim, para evitar que esses sujeitos inerentemente perigosos ficassem impune por suas condutas criminosas, criou-se a noção de periculosidade, que passou a fundamentar a aplicação de um tratamento em saúde a esses sujeitos. Esse novo tratamento tinha base moral, já que os sujeitos não escolhiam a carreira criminosa, mas sim cometiam crimes por sua constituição física e psíquica "inferior". Essa lógica esteve intimamente relacionada aos estudos e práticas racistas no Brasil durante o século XIX (BRANCO, 2019) e teve como seu maior expoente científico Raymundo Nina Rodrigues.

Entretanto, a importância dessa breve retomada histórica é a de demonstrar que o instituto da medida de segurança que se configura até hoje no ordenamento jurídico brasileiro possui raízes racistas, biologizantes e capacitistas, o que revela, para Zaffaroni (2012) que as práticas punitivas hodiernas não estão afastadas da lógica inquisitorial medieval ou do paradigma etiológico-determinista dos séculos XVIII e XIX (BRANCO, 2019). A fundamentação da aplicação de medida de segurança na suposta periculosidade dos sujeitos diagnosticados com psicopatologias preserva a mesma lógica excludente e infringe diretamente a proteção constitucional do princípio da culpabilidade. A utilização da lógica da inimputabilidade para sujeitos com transtorno mental atrelada à noção de que não são aptos para serem culpáveis perpetua justamente a lógica segregadora e preconceituosa de que essas pessoas são inerentemente perigosas e inaptas ao convívio social.

Inclusive, Caetano (2019) ressalta que são muitos os princípios constitucionais infringidos pela aplicação da medida de segurança, pois além do desrespeito ao princípio da culpabilidade, há também infração à legalidade, igualdade, contraditório, ampla defesa, devido processo legal, presunção de inocência e dignidade humana. Portanto, há no desenvolvimento e na fundamentação da medida de segurança violações evidentes aos direitos fundamentais desses sujeitos, bem como resta demonstrada sua ineficácia no tocante ao seu objetivo oficial de tratamento. Por outro lado, a configuração dogmática inconstitucional da medida de segurança parece assegurar com vigor o objetivo real de segregação e exclusão da população diagnosticada com transtorno mental, que já se encontra em situação de enorme vulnerabilidade social. 


\section{Institucionalização e medida de segurança}

A reforma psiquiátrica ocorrida no Brasil nas últimas décadas do século XX e início do século XXI trouxe profundas reflexões a respeito do tema da institucionalização de pessoas com transtornos mentais. Nomes como o de Paulo Amarante e Ana Pitta, no Brasil, de Basaglia e Rotelli, na Itália, foram responsáveis pelo início de um debate acalorado nas áreas envolvendo a psiquiatria a fim de modificar o sistema de internações compulsórias em manicômios e de desumanização dos pacientes. Ao longo de décadas constatou-se que o encarceramento dessas pessoas em lugares insalubres e sem qualquer tipo de atenção ou tratamento digno não era a resposta adequada dentro de um Estado democrático de Direito, já que acima de qualquer condição física ou mental, eram pessoas humanas (YASUI, 2006).

A deficiência sempre foi questão complexa na humanidade e as pessoas que apresentassem qualquer tipo de transtorno ou deficiência sofriam com a qualificação de "sub-humanos". As raízes históricas de condenações à morte, torturas, entre outros tratamentos cruéis fizeram com que os problemas se estendessem até os dias de hoje (MIRANDA, 2004). A obra "Holocausto Brasileiro", de Daniela Arbex, foi capaz de ilustrar o sofrimento a que foram submetidas as pessoas internadas à época no Hospital Colônia, em Barbacena/MG e a autora foi responsável por reviver a memória das pessoas que estiveram frente a um contexto de "holocausto". No prefácio, Eliane Brum comenta o uso da expressão:

As palavras sofrem com a banalização. Quando abusadas pelo nosso despudor, são roubadas de sentido. Holocausto é uma palavra assim. Em geral, soa como exagero quando aplicada a algo além do assassinato em massa dos judeus pelos nazistas na Segunda Guerra. Neste livro, porém, seu uso é preciso. Terrivelmente preciso. Pelo menos 60 mil pessoas morreram entre os muros do Colônia. Tinham sido, a maioria, enfiadas nos vagões de um trem, internadas à força. Quando elas chegaram ao Colônia, suas cabeças foram raspadas, e as roupas, arrancadas. Perderam o nome, foram rebatizadas pelos funcionários, começaram e terminaram ali. (ARBEX, 2013, p. 13).

As memórias retomadas por Arbex são devastadoras e demonstram claramente que as pessoas que ali haviam sido internadas muitas vezes sequer possuíam qualquer tipo de transtorno ou deficiência mental: eram pessoas indesejadas pela sociedade. A autora ainda é capaz de construir as relações interpessoais que esses sujeitos tinham e perderam: diversas mães tiveram seus filhos tirados de si e nunca mais souberam seu paradeiro, e mulheres grávidas passavam fezes em sua barriga para que ninguém fosse capaz de se aproximar e, assim, proteger a gravidez. $\bigcirc$ meio como a jornalista revive a história dessas pessoas é extremamente impactante e traz reflexões de grande relevância para a literatura que se dedica ao estudo da loucura.

O trabalho dedicado pelos profissionais das áreas da saúde no sentido de reorganizar esse sistema degradante, assim, foi essencial para que surgisse o início da conscientização a respeito do 
problema. É evidente que a discussão é ainda muito recente, visto que o próprio Colônia teve seu fim apenas em meados dos anos 90, e por isso a situação das pessoas com qualquer tipo de transtorno mental no Brasil ainda é muito problemática.

Ainda assim, tais reflexões trouxeram reflexos no ordenamento, principalmente com a Lei da Reforma Psiquiátrica (BRASIL, 2001). Lentamente, passou-se a compreender a perspectiva colocada por aqueles que eram favoráveis à reforma psiquiátrica, na medida em que os pacientes passaram a ser encarados como pessoas com necessidades especiais, que deveriam ter acesso ao tratamento adequado para seu transtorno ou deficiência. A referida lei foi responsável por garantir os direitos das pessoas com deficiências em relação ao atendimento a elas dedicado, atribuir ao Estado os seus deveres para com essas pessoas, bem como impedir as espécies de internações que fossem contra a garantia da dignidade dessas pessoas, assegurando o tratamento médico e psicológico adequado.

Também como símbolo desse gradual processo, em 2009 se deu a incorporação da "Convenção Sobre os Direitos da Pessoa com Deficiência", assinada em Nova Iorque, em 2007, por meio de decreto, ao ordenamento jurídico brasileiro, cujo propósito é o de "promover, proteger e assegurar o exercício pleno e equitativo de todos os direitos humanos e liberdades fundamentais por todas as pessoas com deficiência e promover o respeito pela sua dignidade inerente." (BRASIL, 2009). Apresenta princípios e obrigações que buscam a igualdade, respeito à dignidade e não-discriminação, com o ideal de integração efetiva dessas pessoas na sociedade, buscando sua autonomia e respeito pelas diferenças. As mudanças ocorridas no sentido da garantia da dignidade, autonomia, igualdade e não-discriminação das pessoas com deficiência foram bastante significativas nas últimas décadas, apesar de ter se apresentado como uma evolução lenta e gradual em termos de legislação. ${ }^{6}$

Ocorre que, no âmbito do Direito Penal, a fundamentação utilizada para a execução da medida de segurança ainda é muito controvertida e vai no sentido absolutamente oposto dessas garantias construídas ao longo das últimas três décadas. $\bigcirc$ tratamento indicado pelos Códigos Penal e de Processo Penal (BRASIL, 1940, 1941), na modalidade de internação, assim como as penas neles previstas na prática acabam por excluir cada vez mais esses sujeitos de um convívio social saudável (PRADO; SCHINDLER, 2017). Há um claro conflito entre a maneira como o Código Penal institui a medida de segurança e como a Lei da Reforma Psiquiátrica estabelece como ideal de tratamento para os pacientes com transtornos mentais: "Enquanto a medida de segurança é utilizada, em regra, na modalidade de internação, no intuito de tratar e retribuir condutas ilícitas, a reforma surge para percorrer o caminho inverso, desinternar para reabilitar e garantir cidadania à pessoa com transtorno mental." (PRADO; SCHINDLER, 2017, p. 636).

As bases da reforma psiquiátrica seriam a crítica ao modelo centrado no hospital, desinstitucionalização, negação do caráter terapêutico do internamento como regra e

\footnotetext{
6 Vale ressaltar, entretanto, que a partir de meados dos anos 2010 passou a ser configurado um movimento de "contrarreforma" psiquiátrica, a partir da desconstrução manifesta de avanços no sentido da desinstitucionalização e garantia de direitos fundamentais desses sujeitos (BRAVO; PELAEZ; PINHEIRO, 2018; PITTA; GULJOR, 2019).
} 
redirecionamento do modelo assistencial à saúde mental em serviços substitutivos em meio aberto. Inclusive, há vedação expressa da internação em instituições que não garantam expressamente os direitos fundamentais do paciente, previstos no parágrafo único do artigo $2^{\circ}$ da referida lei (SILVA, 2010).

Nesse sentido, em relação à duração da medida de segurança, o Código Penal, por meio da reforma de 1984, prevê que o tratamento se estenderia por tempo indeterminado (BRASIL, 1940, artigo $97, \mathbb{S} 1^{\circ}$ ). Todavia, surgiram alterações e com a Súmula 527, do STJ, o tempo máximo foi estipulado (BRASIL, 2015). Mas mesmo com a referida súmula, não há uma predeterminação para o fim do tratamento, como ocorre com o instituto da pena: ainda é necessária a realização de exame de cessação de periculosidade, que deveria ser realizado anualmente com os pacientes, para que o paciente possa ser adequadamente avaliado. Isso confirma a maior gravidade da medida de segurança em relação ao cumprimento das penas comuns.

De acordo com estudos empíricos, como os de Diniz (2013), Prado e Schindler (2017), e de Azevedo e Capra (2018), sabe-se que muitas pessoas passam décadas internadas em hospitais de custódia, muito acima do tempo máximo delimitado para sua internação. Logo, é possível compreender que a característica dos hospitais de custódia permanece a mesma do século passado, se afastando da busca por um tratamento eficaz aos pacientes. E a medida de segurança sem limitação máxima definida é responsável por agravar o tratamento direcionado à pessoa com transtorno mental em relação ao tratamento dado para os imputáveis.

Destarte, na comparação entre os institutos é possível perceber que existem diversas semelhanças em relação eles, principalmente em relação à execução, mesmo que possuam fundamentos distintos: a culpabilidade no caso da pena e a periculosidade no caso da medida de segurança (PERES; NERY FILHO, 2002). No caso da medida de segurança, é avaliada a possibilidade de ocorrência de um fato perigoso causado pelo sujeito no futuro - e não com base em fatos passados, como é o caso da culpabilidade, fundamento da pena. A indeterminação do tratamento faz com que o sujeito tenha que ser submetido a constantes exames de cessação de periculosidade para a possibilidade de seu término.

Ademais, o conceito de periculosidade dá margem a uma enorme subjetividade na apreciação a respeito do término de cumprimento do tratamento. Não existe qualquer tipo de método científico capaz de prever o comportamento humano e, por esse motivo, a fundamentação da medida de segurança jamais poderia ser em supostos comportamentos futuros do paciente. Afinal, a periculosidade é uma mera suposição de que o paciente apresenta probabilidade de delinquir novamente.

Importante realizar, assim, uma associação entre essa crítica e as críticas realizadas à política criminal atuarial, que prevê a punição com base em critérios pré-estabelecidos que determinariam a conduta futura dos sujeitos. A política criminal atuarial realiza justamente uma previsão psicológica do risco de acordo com condutas passadas do agente, como o uso de drogas, 
reincidência específica, entre outros. Há, assim, um prognóstico da criminalidade, que, nesses casos, estimula a justiça negocial através dos acordos e colaborações em detrimento de investigações bem elaboradas (DIETER, 2013).

O tempo a que o paciente será submetido o sujeito à medida de segurança está intimamente ligado ao tempo que levará para se apresentar como não perigoso em um novo exame (previsto no art. 91, $\$ 4^{\circ}$, do Código Penal). O Código define a periculosidade como a "probabilidade de delinquir", que é diferente da "capacidade de delinquir". Em suma, a primeira se relaciona com conduta futura do delinquente, enquanto a capacidade está ligada com o caso concreto, o crime praticado. Assim, esse fundamento acaba permitindo que haja uma intervenção sem uma determinação concreta (PERES; NERY FILHO, 2002).

O ordenamento jurídico não reconhece a periculosidade como característica do gênero humano, mas sim de determinadas pessoas, e desse modo acaba por presumir a periculosidade da pessoa diagnosticada com transtorno mental, sem a necessidade de avaliação de sua personalidade durante o processo penal, mas apenas para verificar a cessação da periculosidade quando já houve a aplicação da medida de segurança. Isso faz com que a questão passe a girar em torno do sujeito delinquente e não ao crime como fato, configurando-se um verdadeiro direito do autor (WEIGERT, 2017). Em relação ao exame de verificação da cessação da periculosidade os seguintes requisitos desse procedimento são:

a) a autoridade administrativa remete relatório ao juízo da execução, instruído com o laudo psiquiátrico, para decisão sobre revogação ou permanência da medida de segurança, com a antecedência de 1 mês da expiração do prazo; b) a decisão judicial, proferida dentro de 15 dias, é precedida de audiência do Ministério Público e do curador ou defensor, pelo prazo de 3 dias, respectivamente (artigo 175, I-VI, LEP). (SANTOS, 1981, p. 266).

Deste modo, a avaliação a respeito da cessação ou não da periculosidade do paciente é realizada, basicamente, por meio de laudos médicos. A psiquiatria, a psicologia e a rede de apoio das ciências da saúde, nesse sentido, são utilizadas pelo Direito Penal e pelas políticas criminais como mero instrumento de produção de laudos psiquiátricos, ao invés de utilizá-los realmente como uma rede de apoio para o tratamento do paciente.

Há uma restrição crescente do trabalho dos psicólogos em hospitais de custódia e tratamento psiquiátrico, em grande parte justificada pela não integração dessas instituições ao Sistema Único de Saúde (SUS), mas sim às secretarias de justiça e administração penitenciária dos estados. Isso aponta para a ideia de que realmente o paciente não é entendido como alguém sujeito a um tratamento, da melhor maneira a integrá-lo na sociedade, apesar dos grandes esforços dos trabalhadores da área da saúde, mas como um condenado, destinado a permanecer em uma instituição até que deixe de ser perigoso (TEIXEIRA, 2014). 
Há distinção em relação à verificação da periculosidade no processo de entrada e de saída do paciente. Na entrada, são avaliadas características pessoais do agente, relacionadas ao crime cometido; na saída, são avaliados requisitos relacionados ao meio externo e a possibilidade de reinserção desse sujeito na sociedade, como estrutura familiar, entre outros. Os profissionais da saúde, assim, realizam uma crítica a respeito do não funcionamento dessa lógica, já que a instituição do hospital de custódia tolhe a individualidade desses sujeitos e impede que sejam trabalhados aspectos subjetivos em seu tratamento.

Os próprios profissionais da saúde, atuantes na realidade do cumprimento da medida de segurança, compreendem a periculosidade como um conceito "estranho e esvaziado" (TEIXEIRA, 2014, p. 27, grifo da autora). A periculosidade é, assim, um conceito vazio em si e a adoção da medida de segurança visa julgar não o delito, mas a personalidade do paciente, de maneira intimamente ligada à concepção da criminologia positivista. Portanto, o fundamento da medida de segurança é problemático e deve ser revisto na medida em que traz uma punição disfarçada de tratamento e com um fundamento mais gravoso que a própria pena criminal.

\section{Análise de dados}

Para a análise dos dados referentes ao perfil dos internados e das condições a que foram submetidos, foi realizado um estudo analítico de material empírico, com três principais fontes de estudos na área. A primeira fonte foi o trabalho da socióloga Débora Diniz, que realizou um levantamento completo a respeito dos estabelecimentos de custódia e tratamento psiquiátrico no Brasil, com base em dados de 2011, tendo sido sua pesquisa publicada no ano de 2013. A segunda fonte, a pesquisa realizada por Alessandra Prado e Danilo Schindler, no Hospital de Custódia e Tratamento Psiquiátrico da Bahia (HCTP/BA), realizou levantamento de dados nos anos de 2012 e 2013, que foram publicados no ano de 2017. E a última e mais recente fonte foi o trabalho do professor Rodrigo Ghringhelli de Azevedo em conjunto com o mestrando e juiz Luiz Antônio Alves Capra, a respeito de casos de pessoas internadas no Instituto Psiquiátrico Forense de Porto Alegre/ RS no ano de 2017; essa análise envolveu, inclusive, o processo de execução desses sujeitos e foi publicada em junho de 2018.

\subsection{Perfil das pessoas internadas em hospital de custódia}

De acordo com Diniz (2013), o Brasil contava à época do censo de 2011 com 23 hospitais de custódia e tratamento psiquiátrico, cada estado da federação contando com um hospital (com exceção de Acre, Amapá, Goiás, Maranhão, Mato Grosso do Sul, Roraima e Tocantins) enquanto os estados de Minas Gerais, São Paulo e Rio de Janeiro possuíam três unidades cada. Entretanto, um dos estabelecimentos do Rio de Janeiro foi fechado em 2013 (SANTOS; FARIAS, 2014) e 
os estabelecimentos do Amazonas e Piauí foram fechados em 2015 e 2016, respectivamente (AMAZONAS, 2015; PIAUÍ, 2016). A população total era de 3.989 pessoas, das quais 2.839 estavam internadas por cumprimento de medida de segurança (a soma de internações em medida de segurança por conversão de pena era de 117 pessoas).

A faixa etária que concentrava a maior população internada era a de 30 a 34 anos de idade (569 pessoas, correspondente a quase $20 \%$ do total) e a média da idade da população em medida de segurança era de 39 anos de idade, uma vez que havia uma concentração de $42 \%$ das pessoas entre 40 e 69 anos. Em relação ao sexo, mais de $92 \%$ da população era masculina - enquanto no sistema prisional comum essa porcentagem era de aproximadamente $86 \%$, segundo informações do Infopen de 2016.

Em relação à cor, ou raça, das pessoas internadas, ainda na perspectiva de Diniz (2013), $43 \%$ eram brancas e $43 \%$ negras ou pardas (29\% parda e 14\% negra). De acordo com o Gráfico 1, em um comparativo com o sistema prisional comum, é possível notar que a população negra ou parda é bastante mais significativa do que no sistema de internação por medida de segurança; todavia, não se pode deixar despercebido que a quantidade de pessoas que não possuem informação sobre raça na medida de segurança é também bastante relevante (aproximadamente 11\%). Ainda assim, a presença muito menor de pessoas negras corrobora a ideia de que uma "disfuncionalidade" comportamental desses sujeitos a partir de seu diagnóstico de psicopatologia é suficiente para a manutenção de seu encarceramento, fazendo com que a interseccionalidade entre essa categoria de opressão com a de raça só torne a questão ainda mais grave. Essa constatação corrobora a ideia de que a medida de segurança possui como função oculta a segregação e encarceramento de grupos minoritários ao invés de manter as suas práticas aliadas ao discurso oficial de tratamento em saúde mental dos sujeitos com transtorno mental.

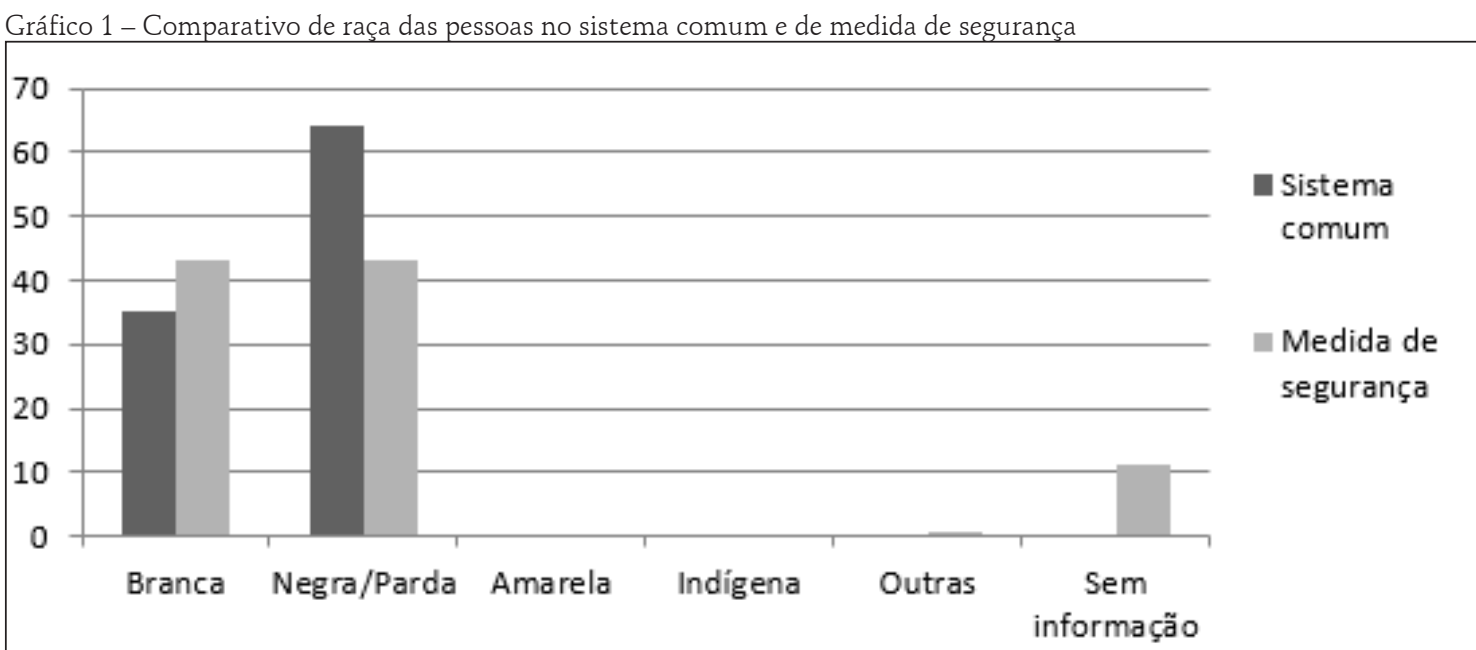

Fonte: adaptado de Diniz (2013) e Departamento Penitenciário Nacional e Ministério da Justiça e Segurança Pública (2016). 
Em relação à escolaridade, os dados são bastante interessantes: assim como no sistema prisional comum, a maior parte das pessoas possui ensino fundamental incompleto. São $51 \%$ das pessoas no sistema comum contra $45 \%$ no cumprimento de medida de segurança. Todavia, quando se analisa os ensinos fundamental e médio completos, a escolaridade no sistema comum é praticamente o dobro. Nesse mesmo sentido, a taxa de analfabetos dentro do sistema de medida de segurança é imensamente maior que no sistema prisional comum: no primeiro são $24 \%$ das pessoas, enquanto no segundo, totaliza-se 4\%. Importante salientar, todavia, de acordo com os dados do Infopen, $6 \%$ da população carcerária foi alfabetizada informalmente, enquanto nos dados compilados por Diniz (2013), não havia qualquer menção a essa informação. De qualquer modo, a diferença é bastante acentuada em relação aos analfabetos, o que indica um acesso ainda mais precário à educação e garantia de direitos fundamentais, em especial aqueles ligados à cidadania dessa população e à promoção de sua autonomia e inclusão social.

Gráfico 2 - Comparativo de escolaridade das pessoas no sistema comum e de medida de segurança

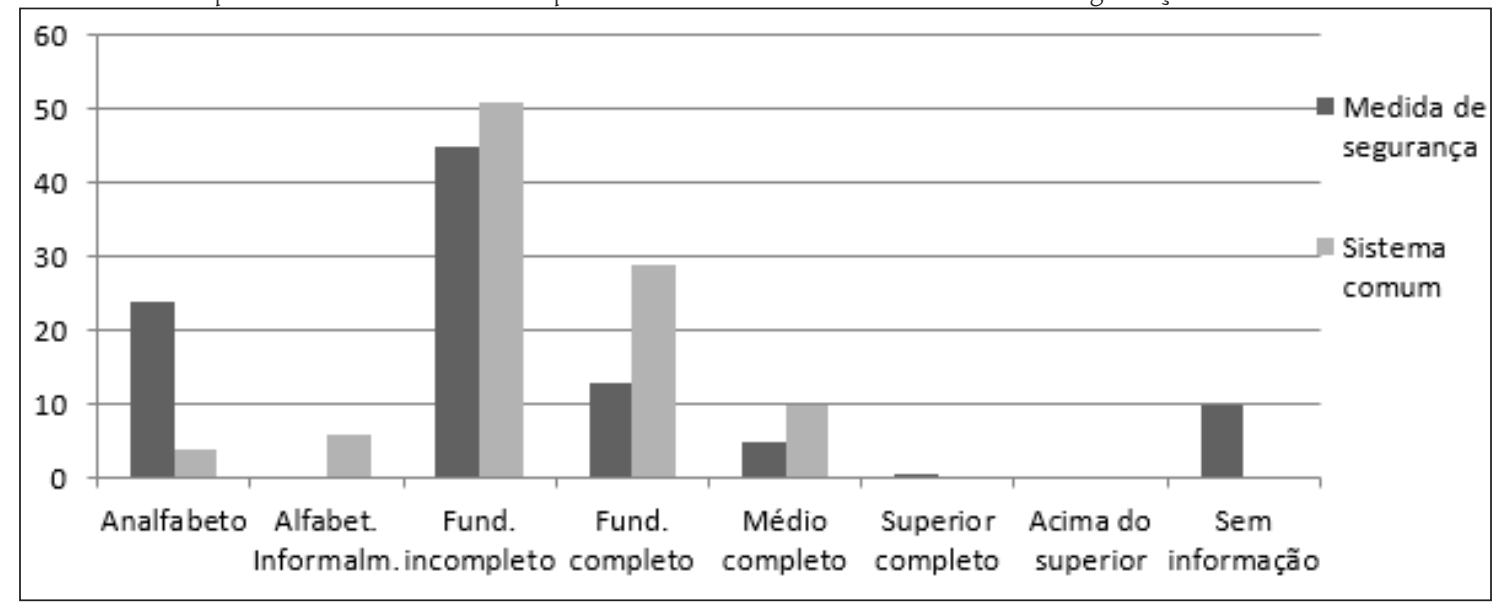

Fonte: adaptado de Diniz (2013) e Departamento Penitenciário Nacional e Ministério da Justiça e Segurança Pública (2016).

Em relação ao estado civil das pessoas internadas por medida de segurança, ainda de acordo com a pesquisa realizada por Diniz (2013), a lógica permanece a mesma do sistema prisional comum, com uma maior concentração de pessoas solteiras, conforme ilustra o Gráfico 3. Ocorre que há uma diferença de quase $20 \%$ entre a quantidade de solteiros no sistema comum e na medida de segurança: $78 \%$ das pessoas internadas por medida de segurança são solteiras, enquanto $60 \%$ são solteiras no sistema prisional comum. A diferença é também muito significativa na união estável: $5 \%$ das pessoas internadas possuem união estável, enquanto $28 \%$ das pessoas presas tem essa situação conjugal. A porcentagem de casados, separados/divorciados e de viúvos, todavia, é bastante semelhante. Pode-se depreender a partir desses dados que as pessoas em medida de segurança possuem uma situação de maior vulnerabilidade a respeito do vínculo familiar: quase $80 \%$ delas são solteiras, portanto já não têm o vínculo marital para o auxílio no processo de reinserção social; assim, dependem de outros 
vínculos familiares que muitas vezes acabam prejudicados ao longo da internação, conforme será visto adiante.

Gráfico 3 - Comparativo de estado civil das pessoas no sistema comum e de medida de segurança

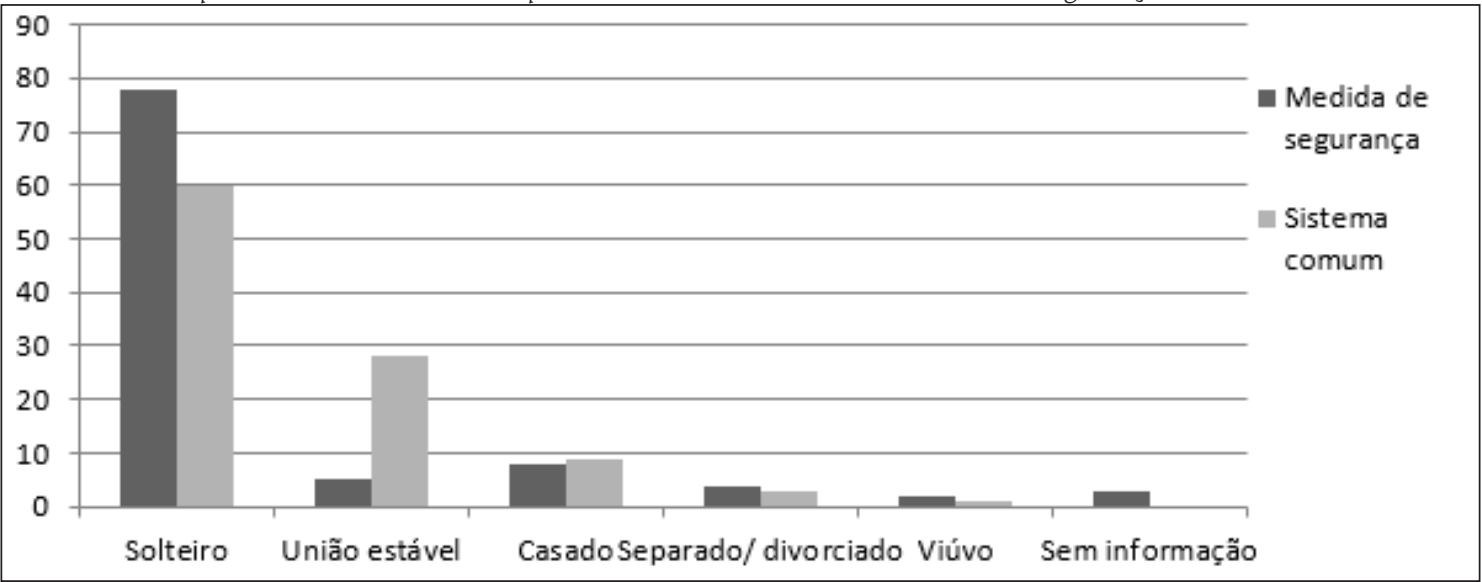

Fonte: adaptado de Diniz (2013) e Departamento Penitenciário Nacional e Ministério da Justiça e Segurança Pública (2016).

Para a análise das espécies de crimes cometidos, foram considerados apenas aqueles que apresentam uma porcentagem maior que 10\% das pessoas internadas, já que essas espécies são muitas. Assim, 15\% das pessoas internadas cometeram crimes contra a dignidade sexual, enquanto $43 \%$ cometeram crimes contra a vida e $29 \%$ crimes contra o patrimônio. Há uma diferença muito significativa entre a população masculina e feminina no tocante aos crimes contra a dignidade sexual: $16 \%$ dos homens encontram-se internados por infração a essa categoria, enquanto apenas 1\% das mulheres se encontra na mesma situação. Foi possível verificar que dentre os crimes patrimoniais, aqueles que possuem números significativos são apenas os de roubo e furto, assim como o sistema prisional comum. Na análise comparativa entre os crimes mais cometidos pela população submetida à medida de segurança, pode-se perceber que o motivo do encarceramento ou internação varia muito de acordo com o sistema a que é submetido e de acordo com gênero.

Homens em sistema comum são mais criminalizados por tráfico e roubo (seguidos por furto e homicídio e tendo apenas $4 \%$ de encarceramento por crimes contra dignidade sexual), enquanto homens submetidos a medida de segurança são internados por homicídios e crimes contra a dignidade sexual, com taxas pouco significativas de tráfico e roubo em relação ao sistema comum.

Já em relação às mulheres, são claramente criminalizadas pelo crime de tráfico, sendo esse o ponto mais destacado do Gráfico 4, enquanto os crimes de roubo, furto e homicídio apresentam taxas mais modestas. Já em relação às mulheres internadas, geralmente o são por crimes de homicídio (o segundo maior índice do gráfico) e, no mesmo sentido, crimes de tráfico, roubo e furto são consideravelmente menores. Em ambos os casos do sexo feminino, crimes contra a dignidade sexual são bastante irrelevantes. 
É muito importante salientar que a espécie de crime pelos quais foram detidos esses sujeitos não necessariamente significa que esses crimes são praticados com mais frequência, senão que são criminalizados (e considerados inimputáveis) com maior frequência por tais condutas. Ainda, a criminalização das pessoas submetidas à medida de segurança é mais frequentemente praticada contra pessoas da rede familiar ou doméstica, "seja porque o louco se mantém em casa e não reconhece a rua como seu espaço de sociabilidade, seja porque a casa é um espaço de risco." (DINIZ, 2013, p. 16).

Gráfico 4 - Comparativo de tipos penais das pessoas no sistema comum e de medida de segurança

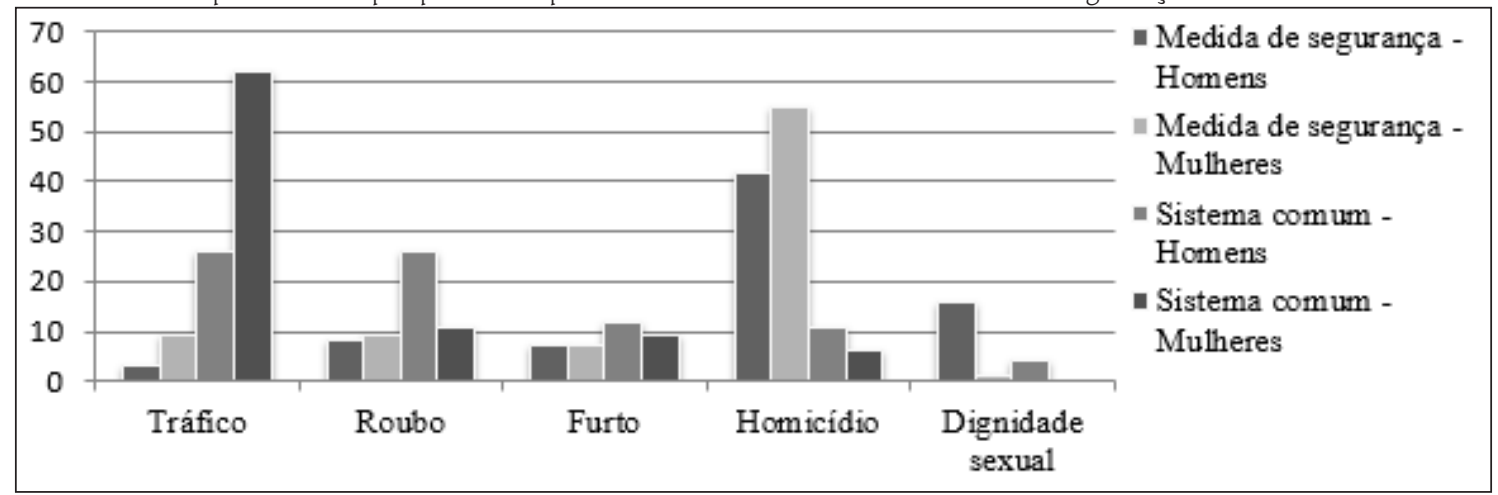

Fonte: adaptado de Diniz (2013) e Departamento Penitenciário Nacional e Ministério da Justiça e Segurança Pública (2016).

Finalmente, o último ponto de análise do perfil das pessoas internadas diz respeito ao seu diagnóstico psiquiátrico. Da população analisada por Diniz (2013), 42\% apresentam o diagnóstico de esquizofrenia; a segunda maior concentração é a de pessoas com retardo mental, representando quase $16 \%$ da população analisada. Pouco mais de $8 \%$ apresentam transtornos mentais devidos ao uso de álcool e outras drogas, e outros transtornos representam porcentagens bem menos consideráveis de incidência.

Essa constatação pode ser interpretada pela importância dada ao diagnóstico nosológico ou classificatório desses sujeitos para a sua criminalização, trazida por Mitjavila e Mathes (2012). Segundo essas autoras, os laudos psiquiátricos utilizados para embasar a aplicação da medida de segurança são majoritariamente fundamentados na mera existência de um diagnóstico de psicopatologia ao invés de se basearem nas circunstâncias subjetivas observadas em cada caso, ou seja, em seu diagnóstico descritivo. A grande predominância de diagnósticos de esquizofrenia entre as pessoas internadas por medida de segurança, portanto, leva-nos a perceber que a lógica observada pelas autoras se confirma e que os sintomas da esquizofrenia estão mais associados a uma noção de periculosidade do sujeito do que em outros transtornos. 


\subsection{Contato do paciente com familiares}

O estudo de Prado e Schindler (2017) demonstra grande preocupação com a questão familiar dos pacientes submetidos a internação, e os autores afirmam que:

A internação afasta mais ainda a família do indivíduo, dificultando sua reinserção social. Em relação aos dados coletados no HCTP/BA, constatou-se que a medida de segurança, embora em algum momento alcance a esperada cessação de periculosidade de pacientes, estigmatiza a pessoa portadora de transtorno mental que passa pelo HCTP, o que contribui para o afastamento ou a quebra do vínculo familiar; aumenta a dificuldade em se localizarem os familiares; e se eterniza quando o HCTP tem desvirtuado seu propósito, pois para não abandonar essas pessoas continua a abrigá-las até que possam encontrar pessoas ou instituições que as recebam. (PRADO; SCHINDLER, 2017, p. 648, grifo nosso).

Muitos dos pacientes ficam por tanto tempo submetidos à custódia que acabam por perder completamente o vínculo com seus familiares e afetos externos ao hospital e, assim, no momento da desinternação não possuem uma rede de apoio externa ao sistema penitenciário. Isso acaba fazendo com que os pacientes permaneçam custodiados em caráter perpétuo, uma vez que o Estado foi capaz de segregá-los de uma maneira tal que eles não possuem qualquer capacidade de voltar a conviver em sociedade. É nesse sentido o relato dos autores Azevedo e Capra (2018, p. 144):

Os dois casos mais longevos de institucionalização verificados no universo pesquisado indicam um paciente com 21 anos de institucionalização, tendo a medida de segurança sido extinta em 10.11.2015, aguardando ele a vaga em residencial terapêutico, assim como um paciente com 26 anos de institucionalização, com alta progressiva deferida, mas em situação de abandono familiar. Constata-se, por fim, que o alargamento de prazos reside, basicamente, em situações de abandono familiar e nas dificuldades encontradas para a colocação dos internos em residenciais terapêuticos.

As análises trazidas pelos autores, assim, confirmam a hipótese de que a execução da medida de segurança, ao menos na modalidade de internação, é absolutamente estigmatizante e despreocupada com o efetivo tratamento dos pacientes submetidos à custódia, reforçando a sua dissonância em relação ao discurso oficial de tratamento em saúde. Uma das principais preocupações com os pacientes psiquiátricos deve ser o contato familiar e sua inserção na sociedade através de seus afetos construídos anteriormente ao início do tratamento, e a institucionalização é, ao contrário, um meio de excluir o paciente da sociedade e privá-lo de contato familiar. Ademais, fica confirmado o caráter punitivo da medida de segurança já que não se vincula ao sistema de saúde; sistema esse que possui perspectiva de intervenção preocupada com a saúde mental e com meios de cuidado do paciente. 


\subsection{Os pacientes e seus documentos pessoais}

Um dos outros problemas trazidos por Prado e Schindler (2017) é a questão da falta de documentação dos pacientes internados. Dos dezessete casos analisados pelos autores, oito deles eram de pacientes com problemas na obtenção ou recuperação da documentação que os identificasse:

Em quatro dos oito casos de pacientes com problemas de documentação, o contato com familiares viabilizou a solução; nos outros, foi necessário realizar identificação datiloscópica no intuito de buscar registros civis preexistentes. Desses, três pacientes necessitaram da abertura de Ação de Assentamento de Registro, por não ter sido encontrado indicativo de identificações anteriores, não constando notícias recentes sobre o andamento do respectivo processo. Diante da carência de pessoal, a Defensoria Pública não estava prestando atendimento constante no HCTP. (PRADO; SCHINDLER, 2017, p. 645).

As implicações práticas e psicológicas dessa questão são extremamente severas. Em termos administrativos, há impossibilidade recebimento de qualquer benefício governamental, como o Benefício de Prestação Continuada; em termos de processo penal, a defesa desses sujeitos é dificultada em grande nível, já que nem sequer sua identidade pode ser confirmada com clareza; há uma enorme dificuldade de se localizar parentes e conhecidos desses pacientes para incentivar um maior contato com ambientes e pessoas externos à custódia; ainda, há a questão de identidade e construção da autoimagem desses pacientes. É possível traçar um paralelo dessa situação com a narrativa de Daniela Arbex (2013, p. 24) sobre os pacientes do Hospital Colônia:

Após a sessão de desinfecção, o grupo recebia o famoso "azulão", uniforme azul de brim, tecido incapaz de blindar as baixíssimas temperaturas da cidade. Assim, padronizado e violado em sua intimidade, seguia cada um para o seu setor. [...] Nessa condição, viam-se despidas do passado, às vezes, até mesmo da própria identidade. Sem documentos, muitas pacientes do Colônia eram rebatizadas pelos funcionários. Perdiam o nome de nascimento, sua história original e sua referência, como se tivessem aparecido no mundo sem alguém que as parisse.

A perda da identidade desses sujeitos, além de burocraticamente complexa, é extremamente simbólica: demonstra o enorme descaso da sociedade para com eles. Ao invés de se direcionar proteção, cuidado e afeto para esses indivíduos, se direciona desídia e exclusão, demonstrando mais uma vez o desinteresse do Estado e do sistema social, político e econômico com a vida e a dignidade dessas pessoas, ou melhor, demonstrando interesse direto em sua segregação como manifestação da estrutura de poder. 


\subsection{Tempo para realização de exame de cessação de periculosidade}

Segundo os dados levantados por Diniz (2013), das pessoas internadas por medida de segurança, $51 \%$ dos casos estavam com o exame de cessação de periculosidade em dia, enquanto $41 \%$ estavam em atraso (em 8\% dos casos não havia informação). Em relação às pessoas internadas por conversão de pena, $60 \%$ delas estavam com o exame em dia, enquanto $35 \%$ estavam com o exame atrasado. A média de atraso era de 32 meses.

Na pesquisa realizada no Hospital de Custódia e Tratamento Psiquiátrico da Bahia, foi constatado que do total de casos analisados, quatro deles não contavam com exames de verificação de cessação de periculosidade, mas possibilidade de substituição por tratamento ambulatorial. Dos outros treze casos, dez se mostraram favoráveis à desinternação (período de 2009 a 2013), dois estavam esperando reavaliação do juiz e no outro caso o paciente veio a falecer (PRADO; SCHINDLER, 2017).

Em relação à pesquisa do Rio Grande do Sul, foi realizado estudo de caso de dois pacientes, e em um deles houve uma série de problemas em relação à produção de laudos. Entre 2005 e 2008, era alegada constantemente a periculosidade do paciente e, assim, a alta progressiva se encontrava demasiado distante. Com a intervenção da Defensoria Pública, houve concessão de indulto, mas essa decisão foi anulada pelo Tribunal de Justiça do Rio Grande do Sul, o que atrasou a concessão do benefício. Com a possibilidade de desligamento, foi traçado um plano, que fracassou e, em 2013, o Poder Judiciário autorizou a permanência do paciente na instituição (AZEVEDO; CAPRA, 2018).

Nesse mesmo sentido, de acordo com o levantamento de Débora Diniz (2013), em 28\% dos casos de pessoas internadas em que já havia exame de verificação de cessação de periculosidade, o laudo atestava para o fato de que a periculosidade já havia cessado. No caso das medidas de segurança por conversão de pena, esse percentual era de $24 \%$. Ainda, em $7 \%$ dos casos, havia sentença de desinternação, e nos casos de conversão esse número era de $6 \%$.

A realização dos exames e laudos necessários para a garantia processual dos indivíduos submetidos à medida de segurança é absolutamente precária e a quantidade de casos com laudos atrasados, bem como a média de atraso de 32 meses, é absolutamente estarrecedora. Conforme dito, já não há uma limitação objetiva para o cumprimento de medida de segurança e a Súmula $\mathrm{n}^{\circ}$ 527, do STJ, buscou apenas estabelecer um limite máximo. Sem a realização do exame e sem seu cumprimento, impossível que haja a efetiva desinternação dos pacientes.

$\mathrm{Na}$ medida em que não há qualquer preocupação no cumprimento e fiscalização dessas garantias processuais de seus direitos fundamentais, os hospitais de custódia passam a se caracterizar como um "depósito de gente". Isso também serve para reafirmar o caráter mais gravoso da medida de segurança em relação à pena criminal. Na prática há um caráter quase perpétuo, já que mesmo com certa limitação teórica, as garantias não são cumpridas e os pacientes são submetidos a tratamentos que duram de acordo com o que o funcionamento burocrático do sistema dita. 


\subsection{Tempo de permanência no hospital de custódia}

De acordo com a pesquisa de Diniz (2013), em relação ao tempo em que os indivíduos submetidos a medida de segurança estão internados, 9\% contavam com menos de um ano, 33\% entre um e três anos, $15 \%$ entre quatro e cinco anos, 18\% entre seis e dez anos, $8 \%$ entre onze e quinze anos, $4 \%$ entre dezesseis e vinte anos, $2 \%$ entre vinte e um e vinte e cinco anos, $0,9 \%$ entre vinte e seis e trinta anos e, por fim, 0,3\% acima de trinta anos. $\bigcirc$ tempo médio de internação era de seis anos e as diferenças computadas entre homens e mulheres não era significativa (DINIZ, 2013). No estudo realizado por Prado e Schindler (2017), constatou-se que existiam dois pacientes internados há mais de 30 anos na instituição, do total de 17 sujeitos da pesquisa.

Em relação aos 117 indivíduos que estavam submetidos a medida de segurança por conversão de pena, $21 \%$ contavam com menos de um ano, 47\% entre um e três anos, 11\% entre quatro e cinco anos, $14 \%$ entre seis e dez anos, $3 \%$ entre onze e quinze anos e $3 \%$ entre dezesseis e vinte anos. Nesse caso, o tempo médio de internação era menor, de quatro anos (DINIZ, 2013).

Em relação aos estudos desenvolvidos no Rio Grande do Sul, constatou-se, ainda, que dos 99 casos de pacientes, 17 deles estavam efetivamente internados, 63 em alta progressiva, sete em desinternação condicional e 12 com a medida de segurança já extinta (AZEVEDO; CAPRA, 2018). Segundo os autores, isso indica que enquanto há uma tentativa de desinstitucionalização (pela grande quantidade de pacientes em desinternação condicional), é claro que a capacidade de efetivar essa desinstitucionalização é absolutamente falha. A justificativa dada para a não desinternação seria o abandono familiar e falta de vagas em instituições alternativas, como as residências terapêuticas.

Complementarmente, os dados comparativos em relação ao maior tempo de cumprimento de medida de segurança em relação à pena em abstrato para a infração são estarrecedores:

Tabela 1 - Os dez indivíduos há mais tempo em medida de segurança se comparado à pena máxima em abstrato para a infração penal

\begin{tabular}{|c|c|c|c|}
\hline Crime & Data da sentença & Tempo da MS & Pena máxima em abstrato \\
\hline Tentativa de furto & 10/10/1979 & 32 anos & 2 anos e 8 meses \\
\hline Homicídio culposo & $30 / 05 / 1979$ & 31 anos & 3 anos \\
\hline Lesão corporal & $10 / 01 / 1985$ & 26 anos & 1 ano \\
\hline Lesão corporal & 03/09/1985 & 25 anos & 1 ano \\
\hline Incêndio culposo & 27/01/1986 & 25 anos & 2 anos \\
\hline Lesão corporal & $27 / 05 / 1988$ & 23 anos & 1 ano \\
\hline Lesão corporal & 20/05/1988 & 22 anos & 1 ano \\
\hline Homicídio culposo & 13/06/1986 & 24 anos & 3 anos \\
\hline Tentativa de estupro e violação de domicílio & $21 / 02 / 1983$ & 28 anos & 6 anos e 11 meses \\
\hline Homicídio culposo & 05/08/1987 & 24 anos & 3 anos \\
\hline
\end{tabular}


A socióloga, por meio dessa tabela, traz uma perspectiva de análise fundamental no comparativo entre o quantum máximo das penas em abstrato e da medida de segurança aplicada a esses indivíduos. Existem inúmeras pessoas internadas por tempo significativamente maior do que o devido no regime de medida de segurança, inclusive, 0,3\% delas estão internadas há mais de 30 anos, o que é absolutamente incabível dentro das normas estabelecidas no Direito Penal brasileiro. Concluem, assim, Azevedo e Capra (2018, p. 153) a respeito desse assunto:

Constata-se, pelos casos estudados, por um lado a verdadeira invisibilidade dos internos no cumprimento das medidas de segurança, invisibilidade esta que autoriza tanto o indefinido prolongamento de uma internação quanto a manutenção de uma internação que não possui suporte em uma sanção penal e, por outro lado, que o sistema, independentemente do esforço que seja desenvolvido por aqueles que o operam, tal qual um objeto que desenvolve um movimento circular uniforme, acaba por retornar sempre ao seu ponto de partida, ou seja, àquela mesma lógica manicomial que se pretendeu combater no país com a Lei Antimanicomial.

Portanto, o fundamento da medida de segurança se mostra absolutamente falho em relação ao seu objetivo oficial e o seu cumprimento mais falho ainda. $O$ caráter da medida de segurança que deveria ser de tratamento dos pacientes com transtornos mentais é na realidade de segregação e de manutenção da lógica de institucionalização. Fica evidenciada novamente uma violação latente aos direitos humanos e fundamentais dessa população, na medida em são penalizados de forma perpétua ao serem internados nos hospitais de custódia e tratamento psiquiátrico.

\section{Considerações finais}

Infelizmente o tempo destinado à produção da pesquisa não permitiu a realização de trabalho de campo e entrevistas com os pacientes internados em hospitais de custódia e tratamento psiquiátrico. Isso principalmente porque há um processo bastante complexo de pedidos de autorização às autoridades competentes para pesquisas que envolvem seres humanos, ainda mais os que se encontram em situação alta vulnerabilidade. Todavia, com a existência de pesquisas empíricas tão completas e lúcidas presentes atualmente na bibliografia, o estudo dos dados foi bastante interessante.

A partir da análise de dados e casos trazidos pelos autores, juntamente com a bibliografia analisada, foi possível perceber que as instituições de custódia e tratamento psiquiátrico não se preocupam com o efetivo tratamento dos pacientes internados. Não por uma falta de atenção dos profissionais da saúde, que possuem grande preocupação com a luta antimanicomial e são os grandes nomes da busca pela desinstitucionalização de pacientes no Brasil e no mundo, mas pela maneira burocratizada e mal fundamentada que se configura o sistema da medida de segurança. 
O instituto, aplicado por meio de absolvição imprópria daquelas pessoas com transtornos mentais que tenham cometido alguma infração penal, se esconde por trás do discurso oficial da redução da periculosidade, tratamento e ressocialização desses sujeitos. Todavia, na prática, configura-se de maneira a buscar a segregação desses indivíduos, afastando-os das suas famílias e afetos externos ao sistema de internação e impedindo sua saída dos estabelecimentos através até mesmo do processo penal, com algumas decisões absolutamente inconstitucionais.

O perfil das pessoas internadas é bastante semelhante ao perfil dos presos, se diferenciando em apenas alguns aspectos, como a maior presença da população negra no sistema comum. De outro modo, a taxa de analfabetismo é muito maior entre os internados, chegando a quase um quarto das pessoas internadas e demonstrando a falta de acesso à educação dessas pessoas (evidente que deve ser considerado que algumas doenças estão ligadas à dificuldade cognitiva no aprendizado, todavia é direito dessa população o acesso à educação regular). O elemento do estado civil também é capaz de revelar sutilmente a situação de abandono das pessoas internadas, já que existem muito mais pessoas solteiras e muito menos pessoas em união estável dentre os internados do que no sistema comum.

Ademais, o fundamento para a execução da medida de segurança colocado pelo Direito Penal é a periculosidade, que se norteia pela "possibilidade de delinquir" desses indivíduos. Desse modo, a base da medida de segurança é a previsão de comportamentos futuros, o que deveria, na realidade, ser afastado imediatamente pelo Direito Penal e pelo ordenamento constitucional brasileiro. Todos os elementos analisados, inclusive, apontam para maior crueldade e gravidade nos tratamentos dispendidos aos indivíduos internados por medida de segurança do que em relação aos presos do sistema comum.

Restou confirmada a hipótese da ineficácia da medida de segurança em seu discurso oficial, o que revela, ao mesmo tempo, a grande eficácia na segregação de pessoas improdutivas para a lógica do capital, das estruturas de dominação e dos meios políticos de produção de verdade. Apesar de não ter sido possível o levantamento dos dados referentes à condição econômica dos pacientes devido à falta de informações nos estudos analisados, a própria condição desses sujeitos é elemento de grande relevância para a sua segregação da sociedade como se configura.

Conforme exposto anteriormente, há um histórico de exclusão dos deficientes que acompanha a necessidade produtiva das sociedades em que se encontram. Deste modo, na sociedade atual, que busca trabalho especializado e intelectualizado, não há espaço para pessoas com transtornos mentais na medida em que não são fonte de produção do capital. São indivíduos que demandam atenção e cuidados especiais, que apenas podem ser dedicados por uma saúde pública de qualidade, que entenda a saúde de modo desvencilhado da lógica produtiva.

Portanto, a lógica de funcionamento dos hospitais de custódia e tratamento psiquiátrico no Brasil vai no sentido contrário do que é proposto a Lei da Reforma Psiquiátrica e acaba por manter a lógica de institucionalização das pessoas com transtornos mentais. Isso é reflexo da aplicação de penas disfarçadas de tratamento a esses sujeitos, bem como da integração desse tratamento ao 
sistema penitenciário e não ao sistema de saúde. E essa lógica confirmada pela pesquisa é fruto de um sistema que possui instituições que buscam a manutenção desse próprio sistema, ao invés de se preocupar com a efetivação de garantias e direitos dos cidadãos sob sua proteção.

\section{Referências}

AMAZONAS. Lei n. 4.213, de 08 de outubro de 2015. Dispõe sobre a modificação na estrutura administrativa do Poder Executivo Estadual, na forma que especifica, e dá outras providências. Disponível em: https://sapl.al.am.leg.br/media/sapl/public/normajuridica/2015/8667/8667_texto_integral.pdf. Acesso em: 15 out. 2020.

ANDRADE, Vera Regina Pereira de. Dogmática e sistema penal: em busca da segurança jurídica prometida. 1994. Tese (Doutorado em Direito) - Centro de Ciências Jurídicas, Universidade Federal de Santa Catarina, Florianópolis, 1994. Disponível em: https://repositorio.ufsc.br/handle/123456789/106397. Acesso em: 12 ago. 2020.

ARBEX, Daniela. Holocausto brasileiro. 19. ed. São Paulo: Geração, 2013.

AZEVEDO, Rodrigo Ghiringhelli; CAPRA, Luiz Antônio Alves. Lógica manicomial e invisibilidade: estudo sobre os internos do Instituto Psiquiátrico Forense Doutor Maurício Cardoso - IPF-RS. Revista Brasileira de Ciências Criminais, São Paulo, v. 144, ano 26, p. 125-158, jun. 2018. Disponível em: http://201.23.85.222/biblioteca/asp/prima-pdf.asp?.codigoMidia=98473\&i-IndexSrv=1. Acesso em: 20 set. 2018 .

BARATTA, Alessandro. Criminología crítica y crítica del derecho penal. 6. ed. Cidade do México: Siglo Veintiuno Editores, 2000.

BRANCO, Thayara Castelo. A (des)legitimação das medidas de segurança no Brasil. 2. ed. Porto Alegre: Livraria do Advogado, 2019.

BRANCO, Thayara Castelo; ÁVILA, Gustavo Noronha de; CARVALHO, Érika Mendes de. A (in) visibilidade das medidas de segurança no Brasil: um estudo empírico das publicações em revistas brasileiras sobre ciências criminais. Revista Brasileira de Ciências Criminais, São Paulo, v. 152, ano 27, p. 499-530, fev./2019. Disponível em: http://ibccrim.dyndns.info:5180/biblioteca/asp/prima-pdf. asp?.codigoMidia=100887\&ilndexSrv=1. Acesso em: 10 ago. 2020.

BRASIL. Constituição. República Federativa do Brasil de 1988. Brasília, DF: Senado Federal, 5 out. 1988. Disponível em: https://www2.camara.leg.br/legin/fed/consti/1988/constituicao-1988-5-outubro-1988-322142-publicacaooriginal-1-pl.html. Acesso em: 6 maio 2020.

BRASIL. Decreto-lei n. 2.848, de 7 de dezembro de 1940. Código Penal. Diário Oficial da União, Brasília, DF, 31 dez. 1940. Disponível em: http://www.planalto.gov.br/ccivil_03/decreto-lei/Del2848compilado.htm. Acesso em: 18 jun. 2018.

BRASIL. Decreto-lei n. 3.689, de 3 de outubro de 1941. Código de Processo Penal. Diário Oficial da União, Brasília, DF, 13 out. 1941. Disponível em: http://www.planalto.gov.br/ccivil_03/decreto-lei/ del3689.htm. Acesso em: 18 jun. 2018. 
BRASIL. Decreto n. 6.949, de 25 de agosto de 2009. Promulga a Convenção Internacional sobre os Direitos das Pessoas com Deficiência e seu Protocolo Facultativo, assinados em Nova York, em 30 de março de 2007. Diário Oficial da União, Brasília, DF, 26 ago. 2009. Disponível em: http://www. planalto.gov.br/ccivil_03/_ato2007-2010/2009/decreto/d6949.htm. Acesso em: 12 fev. 2019.

BRASIL. Lei n. 10.216, de 06 de abril de 2001. Dispõe sobre a proteção e os direitos das pessoas portadoras de transtornos mentais e redireciona o modelo assistencial em saúde mental. Diário Oficial da União, Brasília, DF, 9 abr. 2001. Disponível em: http://www.planalto.gov.br/ccivil_03/ leis/leis_2001/110216.htm. Acesso em: 28 set. 2018.

BRASIL. Superior Tribunal de Justiça. (Terceira Seção). Súmula no 527 . O tempo de duração da medida de segurança não deve ultrapassar o limite máximo da pena abstratamente cominada ao delito praticado. Diário de Justiça eletrônico, 18 maio 2015. Disponível em: http://www.stj.jus.br/ $\mathrm{SCON} /$ sumulas/toc.jsp? processo $-527 \& \& \mathrm{~b}=\mathrm{SUMU} \&$ thesaurus $=J U R I D I C O \& p=$ true. Acesso em: 23 set. 2018.

BRAVO, Maria Inês Souza; PELAEZ, Elaine Junger; PINHEIRO, Wladimir Nunes. As contrarreformas na política de saúde do governo Temer. Argumentum, Vitória, v. 10, n. 1, p. 9-23, jan./abr. 2018. Disponível em: http://periodicos.ufes.br/argumentum/article/view/19139/13218. Acesso em: 17 abr. 2019.

CAETANO, Haroldo. Loucos por liberdade: Direito Penal e loucura. Goiânia: Escolar Editora, 2019.

CARVAlHO, Salo de. Penas e medidas de segurança no Direito Penal brasileiro. 3. ed. São Paulo: Saraiva Educação, 2020.

CONSELHO NACIONAL DE JUSTIÇA. Informativo Rede Justiça Criminal n. 08. Brasília, DF: CNJ, jan. 2016. Disponível em: http://www.cnj.jus.br/files/conteudo/arquivo/2016/02/b948337bc769-0673a39cb5cdb10994f8.pdf. Acesso em: 18 jun. 2018.

DEPARTAMENTO PENITENCIÁRIO NACIONAL; MINISTÉRIO DA JUSTIÇA E SEGURANÇA PÚBLICA. Levantamento nacional de informações penitenciárias: INFOPEN. Brasília, DF: Departamento Penitenciário Nacional e Ministério da Justiça e Segurança Pública, 2016. Disponível em: http:// depen.gov.br/DEPEN/depen/sisdepen/infopen/rela-torio_2016_22-11.pdf. Acesso em: 23 set. 2018.

DIETER, Maurício Stegemann. Política Criminal Atuarial: a criminologia do fim da história. 1. ed. Rio de Janeiro: Revan, 2013.

DINIZ, Débora. A custódia e o tratamento psiquiátrico no Brasil: Censo 2011. Brasília, DF: UnB, 2013. Disponível em: http://newpsi.bvs-psi.org.br/ebooks2010/pt/Acervo_files/-custodia_tratamento_psiquiatrico_no_brasil_censo2011.pdf. Acesso em: 9 set. 2018.

FOUCAULT, Michel. Vigiar e punir. 27. ed. Petrópolis: Vozes, 2003.

GOFFMAN, Erving. Manicômios, prisões e conventos. 8. ed. São Paulo: Perspectiva, 2010.

LANCETTI, Antônio (org.). Saúde loucura: saúde mental e saúde da família. São Paulo: Hucitec, 2001. 
LEBRE, Marcelo. Medidas de segurança e periculosidade criminal: medo de quem? Responsabilidades, Belo Horizonte, v. 2, n. 2, p. 273-282, set. 2012/fev. 2013. Disponível em: http://www.mpdft. mp.br/saude/images/saude_mental/Medida_seguranca_periculosidade_criminal.pdf. Acesso em: 15 nov. 2019.

MELOSSI, Dario; PAVARINI, Massimo. Cárcere e fábrica: as origens do sistema penitenciário (séculos XVI - XIX). Rio de Janeiro: Revan, 2006. v 11. Coleção Pensamento Criminológico.

MIRANDA, Arlete Aparecida Bertoldo. História, deficiência e educação especial. Histedbr, Campinas, n. 15, p. 1-7, set. 2004. Disponível em: http://www.histedbr.fe.unicamp.br/revista/revis/ revis15/art1_15.pdf. Acesso em: 21 mar. 2019.

MITJAVILA, Myriam Raquel; MATHES, Priscilla Gomes. Doença mental e periculosidade criminal na psiquiatria contemporânea: estratégias discursivas e modelos etiológicos. PHYSIS - Revista de Saúde Coletiva, Rio de Janeiro, v. 22, n. 4, p. 1377-1395, 2012. Disponível em: http://www.scielo. br/pdf/physis/v22n4/a07v22n4.pdf. Acesso em: 17 nov. 2019.

PASUKANIS, Evguiéni. B. Teoria geral do direito e marxismo. São Paulo: Editora Acadêmica, 1988.

PERES, Maria Fernanda Tourinho; NERY FILHO, Antônio. A doença mental no Direito Penal brasileiro: inimputabilidade, irresponsabilidade, periculosidade e medida de segurança. História, Ciências, Saúde - Manguinhos, Rio de Janeiro, v. 9, n. 2, p. 335-55, maio/ago. 2002. Disponível em: http://www.scielo.br/scielo.php?script=sci_arttext\&pid=S0104-5970200200-0200006. Acesso em: 22 ago. 2018.

PIAUÍ. Tribunal de Justiça do Estado do Piauí. Programa de cuidado integral do paciente psiquiátrico. Teresina: TJPI, 2016. Disponível em: http://www.tjpi.jus.br/portaltjpi/wp-content/uploads/2018/09/Cartilha-PCIPP.pdf. Acesso em: 15 out. 2020.

PITTA, Ana Maria Fernandes; GULJOR, Ana Paula. A violência da contrarreforma psiquiátrica no Brasil: um ataque à democracia em tempos de luta pelos direitos humanos e justiça social. Cadernos do CEAS, Salvador, n. 246, p. 6-14, jan./abr. 2019. Disponível em: https://cadernosdoceas.ucsal.br/ index.php/cadernosdoceas/article/view/525/424. Acesso em: 3 abr. 2020.

PRADO, Alessandra Mascarenhas; SCHINDLER, Danilo. A medida de segurança na contramão da Lei de Reforma Psiquiátrica: sobre a dificuldade de garantia do direito à liberdade a pacientes judiciários. Revista Direito GV, São Paulo, v. 13, n. 2, p. 628-652, 2017. Disponível em: http://www. scielo.br/scielo.php?.pid=S1808-24322017000200628\&script $=$ sci_abstract\&tlng- $=$ pt. Acesso em: 20 nov. 2017.

RUSCHE, Georg; KIRCHHEIMER, Otto. Punição e estrutura social. 2. ed. Rio de Janeiro: Revan, 2004. Coleção pensamento criminológico. v. 3.

SÁ, Alvino Augusto de; ALVES, Jamil Chaim; ZIMMARO, Rafael Barone. Medidas de segurança: necessárias reflexões pós-advento da Lei de Reforma Psiquiátrica (Lei 10.216/2001). Boletim IBCCRIM, São Paulo, ano 21, n. 249, p. 11-12, ago. 2013. Disponível em: https://arquivo.ibccrim.org. br/boletim_artigo/4929-Medidas-de-seguranca-necessarias-reflexoes-pos-advento-da-Lei-de-Reforma-Psiquiatrica-Lei-102162001. Acesso em: 6 abr. 2020. 
SANTOS, Ana Luiza Gonçalves dos; FARIAS, Francisco Ramos. Criação e extinção do primeiro Manicômio Judiciário do Brasil. Rev. Latinoam. Psicopat. Fund., São Paulo, v. 17, n. 3, p. 515-527, set. 2014. Disponível em: https://www.scielo.br/pdf/rlpf/v17n3/1415-4714-rlpf-17-03-00515.pdf. Acesso em: 16 out. 2020.

SANTOS, Juarez Cirino dos. A criminologia radical. Rio de Janeiro: Ed. Forense, 1981.

SANTOS, Juarez Cirino dos. Direito Penal: parte geral. 7. ed. Florianópolis: Empório do Direito, 2017. p. 421-460.

SEVERO, Cristine Görski. Loucura(s) e família(s): análise de práticas discursivas. Dourados: UFGD, 2009.

SHECAIRA, Sérgio Salomão. Criminologia. 7. ed. São Paulo: Thomson Reuters Brasil, 2018.

SILVA, Haroldo Caetano. Reforma psiquiátrica nas medidas de segurança. Revista Brasileira Crescimento Desenvolvimento Humano, v. 20, n. 1, p. 112-115, 2010. Disponível em: http://pepsic.bvsalud. org/pdf/rbcdh/v20n1/-15.pdf. Acesso em: 29 set. 2018.

SILVESTRE, Giane; LINS DE MELO, Felipe Athayde. Encarceramento em massa e a tragédia prisional brasileira. Boletim do Instituto Brasileiro de Ciências Criminais, n. 293, abr. 2017. Disponível em: https://www.ibccrim.org.br/boletim_artigo/5947-Encarceramento-em-massa-e-a-tragedia-prisional-brasileira. Acesso em: 19 out. $201 \overline{8}$.

TEIXEIRA, Thayse dos Santos. Exame de verificação de cessação de periculosidade: o que avalia? 2014. Trabalho de Conclusão de Curso (Graduação em Psicologia) - Universidade do Sul de Santa Catarina, Palhoça, 2014. Disponível em: http://pergamum.unisul.br/pergamum/pdf/112438_Thayse.pdf. Acesso em: 18 set. 2018.

WEIGERT, Mariana de Assis Brasil e. Medidas de segurança e Reforma Psiquiátrica: silêncios e invisibilidades nos manicômios judiciários brasileiros. Florianópolis: Empório do Direito, 2017.

YASUI, Sílvio. Rupturas e encontros: desafios da Reforma Psiquiátrica Brasileira. 2006. Tese (Doutorado em Ciências da saúde) - Escola Nacional de Saúde Pública Sergio Arouca, Fundação Oswaldo Cruz, Rio de Janeiro, 2006. Disponível em: https://www.arca.fiocruz.br/-bitstream/ icict/4426/2/240.pdf. Acesso em: 29 set. 2018.

ZAFFARONI, Eugenio Raúl. La cuestión criminal. Buenos Aires: Planeta, 2012. 